\title{
Balm in Gilead: Religious Soothing from the Furnace of the Nigeria-Biafra War and Igbo Pentecostal Expressions
}

\author{
Kanayo Nwadialor \\ http://dx.doi./org/10.4314/ujah.v20i1.1
}

\section{Abstract}

Pentecostalism in recent times has become a crucial phenomenon exerting a great influence on the religious, social and cultural life of the Igbo. This is traceable to the social-economic and psychological conditions that prevailed in Igboland during and immediately after the Nigeria-Biafra war. Most of the existing literature on the war seem to be focused on its economic and social consequences with little or no serious attention given to religious yearnings from the furnace of the war particular the growth of Pentecostalism in Igboland. Furthermore, the war appears to be majorly seen by historians from the perspective of the international diplomatic ties between Nigeria and the international communities, without looking inwards to its religious implications. It is on the strength of the above lacuna that this research work was conceived. The study was anchored on the empirical theory of divine intervention as propounded by Thomas Aquinas and observed that disillusionment, poverty and depression that naturally followed the war could not be resolved by the programme of reintegration, reconciliation and reconstruction of the federal government. Similarly, the Igbo people appeared to have lost confidence in the potency of their traditional religious practices as well as the sincerity of the harbingers of mission Christianity, which created an atmosphere of a new religious demand that enhanced evangelization and Pentecostal growth. Like the post slave trade, the post war Igboland saw a balm in 
Gilead from the soothing messages of the Pentecostal movements that promised to heal the wounds of the war. Pentecostalism offered hope, absolute reliance on the divine will on matters of marginalization, poverty and disillusionments that compounded the tragic incidence of the war.

\section{Introduction}

Generally, wars are associated with negativity in all its ramifications. This is because wars have several lasting negative effects on society, some of which can last several years after such conflicts. But in some cases war can open up avenues for some other social phenomena to emerge in the society. Available literature suggests that the Nigeria-Biafra war was generally perceived as having negative implications for the Igbo people, whose territories were the central theatre of the war. However, the fact that Pentecostalism recorded considerable growth during and immediately after the war leads to the question as to whether such growth is one of those social impacts of the war. The NigeriaBiafra war ironically, given the social dislocations as well as the psychological trauma witnessed by the Igbo people significantly led to the growth of Pentecostalism and hence Pentecostal Churches in Igboland.

There were only a handful of Pentecostal Churches in Igboland before the war. Amucheazi (1986) says that the factors that explain why this was so are not difficult to fathom; first, as a movement, Pentecostalism started in 1906 in faraway United States of America. And in fact, by 1906, the Anglican denomination, the Roman Catholics, the Methodists and Presbyterians had gained footholds in Igboland and had made their presence felt by such missionary accompaniment like western education, healthcare services among others. The early 
Pentecostals did not have the funds to start mission schools like the already established missions, which could have attracted membership. As a result of this, the pre- war Pentecostal Churches in Igboland can be said to have been marginal and somewhat insignificant. However, the war was followed by a period of immense instability, characterized by poverty, insecurity joblessness and political uncertainties. As a result, life was made more difficult for the vast majority of Igbo who increasingly turned to spirituality for their basic needs. Some charismatic religious leaders who emerged at that time began to give message of hope emphasizing prosperity gospel which holds that faith is the key to prosperity and social security in this world. They assured a balm in Gilead and attracted hundreds of thousands of poor and middle class Igbo people aspiring to greater wealth and spiritual solutions to the mounting problems emanating from the war.

The metaphor "balm in Gilead" is used here to draw an inference from the experience of Judah and Jerusalem in the thirteenth year of the reign of Josiah when young Jeremiah was commissioned to prophesy a message of doom for a sinful people and nation. But when the truth of that prophesy stared him in the face as he saw the impending destruction of Judah and Jerusalem by the Chaldean army, he lamented bitterly. In complete disgust ha asked, "Is there no balm in Gilead"? (Jer. 8:22).

Balm was a kind of aromatic resin or ointment obtained from a bushy evergreen matrix tree in Palestine. It was an only liquid with a strong but pleasant smell, used as medicine to lessen pain. The balm was therefore used for healing purposes. During and immediately after the war, Igbo people were swiftly passing through a situation of Judah and Jerusalem. The mission Churches were understood as not being able to feed the flock of men and women who hungered for divine remedy for their economic, 
social, political and spiritual ills. Nevertheless, the Igbo believe in religious pragmatism and divine potency that should enable them to overcome their present predicaments. Thus, they rallied round many prophets and charismatic religious leaders who assured God's criteria and methods for effective healing, thereby giving rise to many new religious movements with Pentecostal persuasions.

\section{Theoretical Underpinning}

For the purposes of a theoretical framework this study adopts the theory of Divine Intervention as was propounded by Thomas Aquinas and several other scholars who have left imprints on the original theoretical conception of Aquinas. Thomas Aquinas sets forth in the theory not only to explain the existence of God but to also prove that God intervenes in the affairs of humans. Aquinas' theoretical propositions are to be found in the first part of his book, Summa Theological. In this book, he developed five central arguments for Gods existence and divine intervention in the affairs of men. These arguments, according to Davies (1992) are grounded in an Aristotelian ontology and makes use of the infinite regression argument. First, the theory argues that whatever that is in motion must be put in motion by another thing. So there must be an Unmoved Mover. Aquinas proceeded to argue that God is the Unmoved Mover who moves and influences the affairs of men. Again, the theory argues that it is impossible for a being to cause itself to be (because it would have to exist before it caused itself) and that it is impossible for there to be an infinite changing causes which would result in an infinite regress. Therefore, there must be a first cause, itself uncaused. Furthermore, the theory states that since all beings are contingent (meaning that it is possible for them not to exist); there must have been a time when nothing existed as 
things exist now. The theory thus, contends that there must exist a being with necessary existence regarded as God (Davies, 1992). In all, the Empirical Theory of Divine Intervention claims that apart from the existence of God, He intervenes directly and indirectly in the business of men. The importance of this theory for this study stems from the fact that it gives a philosophical and theological basis for prosperity messages, since God intervenes in the affairs of humans. The strength of the theory is on its explanation that Pentecostal growth and development in Igboland was not based on orthodoxy but orthopraxis in order to change Igbo society for better. The general dissatisfaction of the Igbo following the war opened door for new religious experiences. From deep or ingrained religious psyche, God is a natural experience for the Igbo. Zahan (2000) argued that an African seeks to win the benevolence of God in order to change his or her fortune in a positive manner. It is only God that can destroy enemies and set him or her free. An African calls on God naturally in every life situations because he or she knows that God is capable of making his decision and justice known. This explains why the Igbo, during and immediately after the war, embraced Pentecostalism with his whole life, body and soul and surrendered every facet of his existence to the balm in Gilead as preached by the Pentecostals.

\section{Pentecostalism in Historical Perspective}

Pentecostalism stands for series of revival movements within universal Christianity that emphasise personal encounter with God through the intervention of the Holy Spirit with such features like prophecy, speaking in tongues, vision, healing and prosperity. This can comfortably place Pentecostalism on the same page with Charismatic movements. 
Pentecostals draw their inspirations from the event of Acts 2:4 which occurred fifty days after the resurrection of Jesus and ten days after Christ ascended up into heaven and the Holy Spirit came upon the Apostles and they were empowered to speak in different tongues and perform wonders. Macchia (1996) states that:

It was the day in which the Holy Spirit made a unique visit to the earth to empower his apostles. In a general sense the emphasis of scholars that explored the concept of Pentecostalism centered on the direct personal experience with God through the Holy Spirit. Thus, the Holy Spirit is essentially the main figure of Pentecostalism. (p. 27).

Theologically, Hollenweger (1974) pointed out that, Pentecostalism stemmed principally from Methodism. This is because John Wesley taught and emphasized the doctrine of the Holy Spirit for sanctification as a definite second work of grace to conversion. Beside John Wesley, was Edward Irving who was a Presbyterian minister and a theologian. In contrast to the doctrine of sanctification, Irving taught on the gift of tongue. Synan (2001) pointed out that Irving accepted speaking in tongues as the standing sign and the root and stem out of which flowed all other gifts of the Spirit. Burgess (1998) believes that the first link between spirit baptism and manifestation of speaking in tongues occurred in the ministry of Edward Irving in the 1831. Strachan (1973) saw Irving as a "Pentecostal forerunner as John the Baptist and links directly his standing sign with Pentecostal initial evidence" (p.33).

Historically, Pentecostal origin can be traced to two revivals which were fundamental to the movement as a modern phenomenon. However, there were other revivals in America that preceded the two revivals, such as American Holiness Teachers, 
Wesleyans, Keswick and Camp Meeting Holiness, but they were not recognized as such. It was Parham's revival in Topeka, Kansas that was recorded as the first and William Joseph Seymour of Azusa street Los Angeles as the second revival. Charles Fox Parham was an independent holiness evangelist that strongly believed in divine healing and one of the leading figures of Pentecostal movement. Parham received the teaching of sanctification as the second work of grace. Additionally, Synan (1997) observed that "he also adopted some radical elements of the holiness movement such as faith healing" (p.89). Parham established a school named Bethel Bible School in October 1900 near Topeka, Kansas United States. The school according to Synan (1997) began as a "divine healing home" upon the standard of holiness doctrines. Robert (1979) notes also that upon establishment, about forty (40) students were known to have enrolled into the college with the Bible becoming their only textbook. Subsequently, the students were given an assignment by Perham to discover certain evidence of baptism of the Holy Spiritone of which was concluded to be speaking in tongues. On January 1, 1901, after a night watch service, the students prayed for, received the Holy Spirit baptism. Agnes Ozman was the first to receive the gift with evidence of speaking in tongues through the laying on of hands by Parham. Synan (1997) further echoes that:

This event is commonly regarded as the beginning of modern Pentecostal movement in America. After Ozman experienced tongues the rest of the students sought and received the same experience. Parham received the same experience sometime later and began preaching it in all his services. (p. 91).

From the above it could be argued that modern Pentecostalism originated from the teachings and ministry of Charles Fox Perham. 
However, Goff (1988) argues that "It was rather Parham's doctrine preached by his student Seymour that produced the Azusa street revival of the 1906, and with it the Pentecostal movement became globalized as he expected" (p. 69). Perham had extended his preaching activities to Texas where he began a Bible College in Houston. There, he came in contact with an African American preacher, William Joseph Seymour (1870-1922), a son of freed slaves who would later emerge as the leader of the movement. The movement was to assume an international dimension under his leadership.

Kalu (2008) observes that as the leader of the Pentecostal movement, Seymour in 1906 received an invitation to preach in Los Angeles at a Black Holiness Church, where he laid hands on people and they spoke in tongues. His sermon on tongues, was, however, accepted with hostility leading to the latching of the Church building against him. Consequently, he moved with his members into an old and dilapidating building of the African Methodist Episcopal Church in Azusa Street, Los Angeles:

The revival in Azusa Street during this period became the centre of Pentecostalism-a development which lasted for a short period. There were noticeable waves of immigrants from all over the western world to the street of Azusa with the aim of acquiring personal experience of the new trend as well as to be baptized in the Spirit. Reports from the press during this period contributed in promulgating and consequently, internationalizing the spiritual activity in Azusa Street, leading to the birth of other Pentecostal missions. (p. 31).

Cerillo (1977) points out that the 1906 revival at Azusa Street Los Angeles marked the second phase of Pentecostal 
origins. William Seymour an African-American Holiness Preacher ignited the revival. This, therefore, means that the Pentecostal movement started with a teacher and students in Topeka. But when they discovered the gift of the Holy Spirit with evidence of speaking in tongues, it attracted Christians from other movements and denominations that took the message back to their various places. First it was taken to Azusa Street, Los Angles by William Seymour, one of Charles Parham's students and from there it went global with the aid of people who came from different parts of the World and had the same experience.

Explaining the phenomenal spread of Pentecostal, Miller (1996) has reported that, "Pentecostalism often attracts people who are suffering from what sociologists refer to as 'anomie'" (p.22). Anomie is the state of alienation and social disorientation that people who have moved from rural to urban centres feel. Also, people who have crises situations in life are prone to follow Pentecostalism; these crises may be financial, health, social, psychological, etc. Pentecostalism offers a kind of balm like the one in biblical Gilead by which crisis situations are managed.

Pentecostalism has continued to expand in major parts of the world in different forms. For instance, prophecy is a very important aspect especially in Africa, where oracular prophecy fulfils many pastoral and therapeutic functions. Thus Anderson (2004) writes that Africans have taken these three-fold functions further and have become counsellors, pastors and healers at the same time, solving human needs of those who consult them. This in turn leads to the issue of indigenization and diversity that occurs in Pentecostalism. The movement with its flexibility in the spirit has an innate ability to make itself at home in almost any context. It has continued to expand in many different forms throughout the world. For Anderson (2004), this is largely because of the 
flexibility in the spirit, which often allows them more freedom in developing their own cultural relevant expressions. Pentecostal message is believe to be supposed to improve individual and community's needs and also bring greater awareness of love of both God and one's neighbour. This is also supported by Taylor (1972), who notes that the issue of indigenization has caused the movement to expand in many different forms throughout the world, with emphases on the needs of such communities or cultures.

\section{Early History of Pentecostalism Igboland}

Pentecostalism was not a serious Christian system in Igboland before the Nigeria-Biafra war because at that time the Christian missionary ideology bred a society of Igbo people who were strongly attached to the value of Church membership. Church membership according to Kalu (1978), was seen as a part of modern life and hence a fashionable mode of life, while traditional religious life was seen as an outdated mode of life. Thus there was a boost in Church membership (by Church here we mean mission Churches). The organizational structure of the Church was so firmly parish based, and people's sense of Church membership was so high. Though a number of pseudo-Pentecostal movements sprang up in some parts of Igboland but ebbed as rapidly as they had grown. In most cases, the death of the founders brought about an almost immediate end to the movements. However, these indigenous Christian movements have to a very large extent motivated the spread and development of Pentecostalism in Igboland.

The impetus for introducing early form of Pentecostalism in Igboland was provided by the Prophet-Evangelist Garrick Sokari Braide. According to Tasie (1978), Braide was born in Obonoma, 
one of the small villages of the present day Rivers State in 1882. Garrick Braide was enrolled in the village Church (Anglican Communion) in 1906 and in January 23, 1910, at St. Andrew's Anglican Church in Bakana, he became a Christian and was baptized. Two years later (1912), he was confirmed by Bishop James Johnson, the then head of the Anglican Church in the Niger Delta. Though he was an Ijaw man, he had to learn the Anglican Church Catechism in Igbo language, the then official language in the Niger Delta Pastorate. He was taught how to read and write and how to learn the Ten Commandments, the Lord's Prayer and the Apostles ' Creed in Igbo before he was baptized.

Tasie (1978) further says that Braide made his first public claim in 1912. He was earlier noted for his enthusiasm and religious exercises, which he later felt called by the Lord Jesus Christ into the Christian Ministry and was accepted as a lay preacher in the Anglican Church of the Niger Delta Pastorate. Before 1912, there were stories making round or circulating about his prophetic and healing gifts. Ewechue (1991) puts it this way:

By 1916, his revivalist movement had spread to many parts of the Church Missionary Society (CMS) as it was called or Anglican Communion now-in the Niger Delta Pastorate and also to the Southern Zone of Owerri District. He made tremendous successes in prophetic healings, accurate revelation and display of spiritual gifts. (p. 34).

Garrick Sokari Idaketima Marian Braide died on January 15, 1918 following an illness resulting from about two years imprisonment by the colonial administration who might have connived with the foreign missionaries of the C.M.S to stop the Braide's movement that was seen as a threat to foreign presence in the area, but before his death, his movement has caused much religious fervour especially among some Igbo traders in the Niger Delta who got 
converted and either carried the movement themselves to their localities or beckoned on the evangelist to introduce the movement to their people. Inyama (2007) states that "by 1920, the Braide movement had stations in and around Owerri, including Mbieri, Uruatta, Nekede, Amaeze, Iriamagu Ihiagwa, Amaorie and Emeabiam" (p. 65). After his death, his followers founded the Christ Army Church.

\section{The Naked Faith People}

After the first wave of Pentecostalism to Igboland led by Garrick Braide, a group of Christians began to operate outside the mainline Churches, preaching absolute reliance on the power of the Holy Spirits for healing of all kinds without taking any other form of medicine. They were called Naked Faith People by Kalu (2000). According to him, "they carried out an enduring missionary enterprise without missionaries, operating the field by a remote control through tracts and correspondence and, thereby short circuiting all the cultural and civilizing baggage of denominational missionary endeavour" (p. 265). A typical example of this type of movement was the Faith Tabernacle. Inyama (2007) writes that:

The Faith Tabernacle started at a prayer ground in an Anglican Church St. Saviour's Ijebuode. They prayed for healing during the world influenza of 1918. Faith Tabernacle later became Christ Apostolic Church. Its appearance in Igboland after the activities of the Garrick Braide movement and the consolidation of the European missionary Churches was very significant. It was a non charismatic organisation but mopped up the charismatic outpouring, especially what would seem the debris of the Braide's movement, and welded them into a "faith full body". (p. 68). 
They adopted an ascetic and world denying life style and theology that emphasized the urgency of all and sundry to hear the world of God since they stressed that the world was soon going to come to end. Faith Tabernacle movement made a tremendous inroads into Igboland especially after world war 1 had occasioned the influenza pandemic that made health issues paramount among the people. Under such conditions, Faith Tabernacle witnessed a phenomenal growth as they promised a balm in Gilead to the influenza pandemic.

Worthy of note is the fact that Assemblies of God Church in Igboland could be considered an offshoot of the Faith Tabernacle. Augustine Nwogu was a member of the Faith Tabernacle who was ejected on the account of his claim to have being empowered by the Holy Spirit to speak in tongues against the teachings of the Faith Tabernacle. He founded the Church of Jesus Christ where he continued with his followers until the taking over of the new group by the Assemblies of God Church in 1939. However, the effect of the Assemblies of God Church was not deeply felt in Igboland until during the Nigeria-Biafra war.

\section{Campus Pentecostalism in Pre-war Igboland}

From the 1930s students evangelical groups began to blossom in Nigerian universities and colleges. These were the Student Christian Movement and the Scripture Union. According to Inyama (2007), "The magazine and tracts tradition of the Naked Faith people blossomed in evangelical movements among colleges and university students from the 1930s" (p. 73). Achunike (2009) asserts that:

Introduced principally from Britain between 1937 and 1955, the Christian Student Movement (CSM) and the Christian Union (CU) were firmly established in Nigerian 
institutions before the 1970s. In January 1970s some (CU) students of University of Ibadan who interacted with the Pentecostal Church claimed to be spirit baptized and spoke in tongues. They influenced the CSM members. In May 1970 members founded a new group, World Action Team for Christ. Through their evangelical outreaches the six Universities in the country then experienced the revival. By late 1972 the influence of the American Pentecostalism was noted largely through literature. (p. 16).

Again, it is observed that these students took the experience back to their mainline Churches such as the Anglican, Methodist, Evangelical Church of West Africa (now Evangelical Church Winning All) and Baptist. This eventually gave rise to the emergence of Charismatic Movement in the Protestant Churches. Ojo (2013) observed that the rise of this movement was made possible through contacts between Pentecostal ministers and evangelical students in higher institutions and the persistent circulation of Pentecostal literature from North America and Europe. Ojo (cited by Inyama, 2007) continues that:

The Student Movement was established as a mission oriented organization in British universities in the great missionary era of the $19^{\text {th }}$ century. Its rapid growth was sustained by the enthusiasm for foreign missionary work...as many students pledged to volunteer for missionary work after graduation. (p. 73).

Two Nigerians, Akanu Ibiam and Theophilus Ejiwumi, who studied in Britain, brought the movement with them on their return. Akanu Ibiam brought this movement to Igboland.

The Scripture Union was founded in 1867 in England to provide special services for neglected children from Victorian Churches but daily Bible reading was later incorporated into their 
activities. The missionaries of the Church Missionary Society brought this group into Nigeria but its influence was restricted to Anglican circle. The movement was later introduced into CMS secondary schools and as the secondary school students graduate into the universities, the movement became more of as campus fellowship. The movement emphasises Bible study and individual Christian commitment. The activities of this movement was mainly within the campuses with emphasis on studios reading of the Bible, until the universities were closed down following the outbreak of the war which in turn transformed the movement into an evangelical group moving from village to village as they fled from the war engaging in deep conversion, deliverance, village evangelism and relief work. Its reputation spread like wildfire as young people formed prayer and evangelistic bands in their villages. By 1969, the character of the Scripture Union changed tremendously as people gave their lives to Christ in large numbers, and healing occurred during many hospital visits. Many writers trace the root of Igbo Pentecostalism to Scripture Union.

\section{Prayer House Pentecostalism in Pre-war Igboland}

Another element of pre-war Pentecostal movements in Igboland was the "Prayer House" movements which sprang up as a somewhat offshoot of the Aladura movements. Most founders of the Prayer House movements were members of the mainline Churches who at one time or the other and for one reason or the other had attended the Aladura prayers and had been so influenced. The difference between the two is that members of the Prayer House still fulfil some membership obligations to some mainline (orthodox) Churches while those of the Aladura have completely broken away from the orthodox Churches and constituted themselves into their own independent Churches. 
During the period between the political independence of Nigeria and the subsequent civil war of 1967-1970, the orthodox Churches were almost in the same spiritual state as ordinary social groups. Describing the spiritual state of the Churches of this period, Bolton (1992) notes that:

The Church was in exactly the same state as the nation, in darkness. There was virtually no life in the Churches. As the Lord Himself said, 'if then the light in you is darkness, how great is the darkness (Matthew 23). Every Sunday morning, for as long as I can remember, hundreds and thousands and even million of Igbo flocked into the Churches; Anglicans, Methodists, Baptists, Presbyterians, Catholics, all sorts of denominations. But most of them would have died and gone to hell. Most of them believed they were saved through being baptized and through being good. We probably knew that Jesus died for our sins, whatever that was, but it means little or nothing. Liberal theology reigned. Very few people believed the Bible. And virtually everyone believed the age of miracles in the church was past. If one wanted spiritual power one became or consulted an occultist, spiritualist or a native doctor. And there were many of these. People wanted a reality and a spirituality that eluded them. But it certainly would not have occurred to them to look for this spirituality in the Churches. The Churches had a form of religion but denied the power of it. (cf. II Timothy 3:5. (p. 5).

It was in this atmosphere of spiritual paucity and poverty that Prayer House movements began. The Prayer House groups not only prayed a lot, they also preached from the Bible. It is therefore, right to say that those who became the cardinal Evangelicals and 
Pentecostals in Igboland had themselves been involved in one prayer house or the other and it was from there that most people who had a thirst for the deeper spiritual things began.

Agnes Okoh (later the Holy Prophetess Odozi-Obodo) claimed a call to ministry through divine revelation after being healed from a long-standing illness. In 1947, she opened a prayer house in Onitsha, and gained a large following due to her healing and prophetic gifts. After a visit from a group attached to the Christ Apostolic Church, Western Nigeria, she called her prayer house Christ Apostolic Church Odozi Obodo, and in the early 1970s it was registered as Christ Holy Church. It fits the profile of the evangelical-type prayer house described by Kalu (1978) due to its strong Christological and evangelistic emphasis. Christ Holy Church describes itself as a Pentecostal, spiritual, and evangelical Church, upholds the Bible as the word of God, and in its mission statement claims to 'worship the triune God in holiness.

Iwuagwu (1976) notes also that during the 1950s, other Igbo-founded prayer houses emerged. Perhaps the most popular was the Ufuma Practical Prayer Band (UPPB), which had important links to the Civil War Revival. Established in 1958 as a fellowship affiliated to the Anglican Church, UPPB developed around the ministry of a prophetess called Madam Nwokolo, and its popularity rested upon her apparent healing ministry and the group's strong interdenominational emphasis. Since the 1970s, it has become an independent body with branches throughout Nigeria. Ufuma Practical Prayer Band fits the profile of Zionisttype prayer house described by Kalu (1978) due to the ritual nature of its liturgy (which included fasting, the use of candles, 'holy water', and oil for healing), its lack of a clear Christological focus, and its reluctance to engage in evangelistic activity. 
Chuta (1986) also points out that the 1950s saw the emergence of the first of many Igbo-founded sabbattarian groups, the Christ Healing Sabbath Mission, founded in 1956 by Mark Onuabichi. These prayer houses vary considerably, ranging from those that incorporate traditional practices, such as ancestor worship and animal sacrifices, to those with a more Christological focus. Their roots in Igboland go back to Dede Ekeke Lolo, who was briefly associated with the Garrick Braide movement. During the 1960s, they multiplied and diversified, attracting clients from mainline Churches, including some who subsequently became involved in the Civil War Revival.

Specifically, Burgess (2008) notes that Prayer houses from Western Nigeria arrived in Igboland in the 1940s, but did not become popular until after the war. One factor that made most Igbo people not to accept these Churches in the pre-war period was the predominance of mission founded Churches in the area. There was also propaganda and prejudice against these movements by the leaders of the mission founded Churches. The idea, according to Inyama (2007) was that "whoever joined such movements was having a mental problem and or was inviting problem into his family as they would come with their prophecy and "occultism" to plant seeds of discord in the family" (p. 85). However, the situation of the war precipitated such conditions that made Igbo people to run into these Churches as their healing ministry became popular due to unavailability of all forms of orthodox medical services. The Igbo also felt disappointed with the mission Churches not only on the accusation that they would have connived with British government to colonize Igboland and amalgamated the Northern and the Southern parts of Nigeria which was believed to have laid the foundation for the war, but especially as Britain was seen as supporting the Nigerian troop against Biafra 
during the war years. Igbo people were further disappointed in their traditional deities for not being able to protect them from external aggression. Thus, the stage was set for the Igbo to reach out for a balm in Gilead within the Pentecostal missions.

\section{The Nigeria-Biafra War and the Igbo Yearnings for a Balm in Gilead}

Missionary Christianity in Igboland before the civil war had been imaged by certain evangelicals as being "dead", marked by formalism and lethargy. This was beside the accusation that mission Christianity was the spiritual arm of the British imperial mission in Igboland who supported the genocide of Biafrans. Another factor was the departure of expatriate missionaries and the flight of local Church clerics in the face of threat, which left the congregation short of leaders. The rigidity of hierarchical structures and dependence on ordained ministry made it difficult for the congregations. The resulting effect was series of revolt in the mission Churches manifesting in songs that became a means of discouraging people from membership of the mission Churches. The old European based hymns were discarded by Igbo Christians and "Native air" composed in their stead. Such "Native air" enabled the people to express their sorrows of the war. The implication of this was that mission Christianity was implicated as a snare which should be abandoned for another type of Christianity that could be more beneficial. This is how Inyama (2007) puts it. The war image of mission Christianity was such that Britain, the precursor and bearer of the Christian religion, supported the Muslims against the Christians.

On the other part of the traditional religion...the war demystified the already bifurcated traditional religion to such a state of utter disillusionment. There were increased traditional 
religious activities during the war especially those aspects that emphasized control, divination, protection and magic. This was to solve the pressing problems and to ward off danger. The traditional religion was called to battle after a long dormant period, to fight an enemy with a stronger fire power. Most of the Biafran soldiers wore amulets and talisman which they believed could protect or make them invisible before the bullets. However, Inyama (2007) bemoaned that the hope placed on Igbo traditional deities were dashed as they could not protect the soldiers from the superior power of the federal troops. Not only has the spirit of the traditional religion been decimated but, their external and physical features were assaulted. The war uprooted people from their local communities, loosening their ties with ancestors and shrines. Aniebo (1983) said that the war made people to take refuge in the dreaded evil forest reserved for deities, trampling upon the sacred objects which "kill ordinary people" and they did not die. Sacred groves and shrines were used for Church gatherings and other social services. Totem animals that kept the awe around the local deities became staple meal for the people due to extreme starvation. In consequence, many Igbo people became disillusioned with the traditional religious practices and potency. There came a new desire for alternative religious affiliation. The praying houses that began to proliferate in Igboland in the wake of the war became an alternative to fulfil Igbo traditional religious spirituality.

The Igbo believed in a spirit world that has direct contact and control of the physical world. This accounts for why the Igbo would do all things possible to entreat the spiritual beings, either to curry their favour or to avoid their punishment. Mission Christianity played down on such belief and dismissed it as mere superstitions, thereby creating a religious vacuum in the Igbo 
spiritual existence. These praying houses with their characteristic visions, prophecy, dreams and ecstatic worships appealed to the Igbo religious yearnings after the war, thereby boosting the popularity of Pentecostal movements as Kaiing (cited by Inyama, 2007) puts it:

Dreams, visions and prophecy all relate to the desire for meaningful and personal communication with God. Tongues are considered to be a visible sign that God is present and has given the Holy Spirit to an individual. Healing indicates that God's power is available. Signs and wonders are sought not for their own sake, but for their ability to transform the lives of Christians and to draw unbelievers to Jesus Christ. (p. 89).

So in their efforts to implore divine intervention to provide solution to their desperate situation, the Igbo resorted to visiting prayer houses and healing homes. This they did because the effort of the mission Churches who though instituted orphanages, led prayers for the people, provided medical services, clothing and food; were perceived as incapable to provide the required solution. There was some air of confusion among the people as they were enticed away in the search for more immediate welfare alleviation by the radical prayers of the Pentecostals. Achunike (2000) states that:

There were many refugees in the war period. Before the war, the established Churches had attained stability...hardship, social tensions, dreadful sickness like kwashiorkor, refugee lifestyle and psychological problems which the mainline Churches could not offer solution, diverted the attention of many Igbo towards the Aladura Churches and prayer houses which are springing up at an 
alarming rate at this time and promised to offer solutions to some of the problems. (pp. 55-56).

The above remarks by Achunike gives the picture of the Igbo people in desperate yearnings for a soothing balm to their war associated socio-economic situation. The prayer houses and Pentecostal movements displayed unique capacity to entreat the power of providence for human benefits. The popularity of these prayers houses rested on their close affinity to Igbo traditional piety, their pragmatic approach to religion and their promises of protection and security. Many people who equally needed rehabilitation took to opening of prayer houses, not for sincere religious/social welfare services to the people but as a way of alleviating their own problems too, as the people would contribute money to the prayer houses. The true situation and their later consequential instances were hidden under the platform of attending to immediate confusion and problem created by the war. The period was characterized by severe economic hardship for the Igbo society, Pentecostalism presented the gospel as an answer to financial hardship caused by economic decline. The prosperity teaching which links faith with the expectation of material wealth and success contributed to the Pentecostal appeal especially among young people concerned with success and progress. Thus, Pentecostal emphasis on the Bible, innovative worship style, community ethos and proclamation of a holistic gospel appealed to the Igbo people who were faced with disintegrating social and economic relationships.

Mention must also be made of the fact that mission Christianity that started operating in Igboland in the middle of the nineteenth century had created an educated class of Igbo people through their school approach to evangelism. This watered the ground for the proliferation of Pentecostal movements through 
their correspondences and tracts system of spreading their message. Inyama (2007) echoes that "The magazine and tracts tradition of the Naked Faith people blossomed in the evangelical movements among colleges and university students from the 1930s" (p. 73).

The emerging Pentecostalism could not but be seen as a divine effort at providing the soothing balm for the numerous Igbo people who were wounded emotionally, psychologically, financially and physically by the war. The war further broke the unholy alliance that existed between the colonial agents and mission Christianity on one side, and the local chiefs on the other hand, thereby ending the period of intrigues, mischief and frustration of the Pentecostal movements and creating a fertile ground for other forms of religious expression.

Shortly after the end of the civil war in 1970 as Burgess (2008) would say, many Igbo charismatic leaders began to found new religious movements with Pentecostal persuasions. For instance, in 1972, Gabriel Nwokolo returned home from Kaduna due the 1966 pogroms and joined the Scripture Union Umuahia. During the war, he became an itinerant preacher and subsequently in 1972 started Last Days Messengers in Okigwe. In 1976, Holiness Evangelistic Mission (Now Holiness Evangelical Church) was founded which became the first major Pentecostal Church in Owerri. Riches of Christ Mission began in 1973 as an evangelical movement in Igboland led by Edozie Mba, Paul Nweke (now Nwachukwu), Augustine Nwodika, Emeka Eze and Charles Nwafor. Within two years, it had branches in some major Igbo cities like Onitsha, Enugu and Aba. In 1974, Christ for all Mission in Onitsha was founded by an Anglican and Scripture Union Leader-Benson Ezeokeke. Then Save the Lost Mission in Nnewi was founded by Tony Okeke, a former Roman Catholic. Kalu 
(2008) notes further that the hour of freedom members itinerated all over the Eastern region with a vibrant evangelical fervor at the end of war in 1970 from Onitsha. They built a support network of prayer groups, as many young people from schools Hocked to the outreach programmes. Many were members of the Scripture Union. Within a decade, a revival hit Igboland. The hour of freedom became famous as healings and mass conversions occurred in one town after another. Prayer Bands were formed in various towns such as Enugu, Owerri, Aba and more. Many young people who constituted bands of itinerant evangelists following the closure of schools after the outbreak of the war gallantly took their Pentecostal enthusiasm to many local Igbo villages. Many who were earlier attracted to prayer houses caused splits within these prayer groups to form classical Pentecostal Churches. For instance, Christ Ascension Church splintered and the leader of the young rebels, Mike Okonkwo, formed a Pentecostal Church named the True Redeemed Evangelical Mission. Kalu (2008) continues that the explosion of this Pentecostalism is credited to the youth, both in secondary and tertiary institutions who created a new culture of Pentecostalism in which the leadership was more highly educated than in the earlier pneumatic challenges by the Aladura or the prophetic movement. But despite the higher level of education, the fluid dynamism in a spirit-driven movement deconstructed the Western model of the mission Churches. Burgess (2008) adds that immediately after the civil war, three young Anglicans namely, Stephen Okafor, Arthur Oraizu and Raphael Okafor revolutionized the contemporary Pentecostal conception in Igboland. Before then, they were members of the Ufuma prayer House as it was commonly called. The author notes that, Stephen, Arthur and Raphael eventually had personal encounter with Jesus Christ and left the prayer band and began to preach the gospel of repentance 
and salvation through faith in Jesus Christ. They became the foundation members of a brand of Scripture Union which became a Pentecostal movement rather than an evangelistic agency in the Anglican Church. Thus, a Pentecostal wind began to blow in Igboland and consequently many discovered that they possessed spiritual gifts. The face of Scripture Union gradually changed, and it moved from evangelical to a Pentecostal exhibition of the charismata especially as the leaders of the Anglican Church expelled some members of the $\mathrm{SU}$ on account of their speaking in tongues and faith healing, leaving them to set up their own Pentecostal movements. Achunike (2004) gives credence to the above as he observes that many of such Spirit-filled Christians within the Scripture Union as they called themselves, most of whom were Anglicans, withdrew from the mission Churches and founded their own Churches while the rest constituted themselves into a strong Pentecostal factor in the Anglican Church and other mission Churches. In the Anglican Church, the Pentecostal factor came to be known as the Evangelical Fellowship in the Anglican Communion (EFAC).

\section{Conclusion}

The American Civil War was a very significant factor leading to the spread of Pentecostal spirituality at the beginning of the 20th century in America. Depression and general malaise of the populace are logical consequences of war. Nevertheless, the effects and ruins of war called for a reflection on the reality of private responsibility and the societal renewal. This situation offered fundamental religious motives for Pentecostal renewal. Pentecostalism found a natural ambient in Igboland as the NigeriaBiafra war, just like any other war, infested the people with usual ravaging characteristics of war turn area. The people were 
confronted with lots of social, religious, psychological, political and economic problems which were yearning for immediate attention and solution; anything that seemed to alleviate the hopeless situation was most warmly welcome. The mission Churches did not seem to have the immediate and adequate answer to the hopeless situation and the rehabilitation of the displaced refugees. In their desperate yearnings for a soothing intervention and being a people who are deeply religious, they resorted to prayer houses for intervention. At this time the prayer houses and Pentecostal movements showed themselves vestibules of the divine to reach the people with a soothing balm for their teething situation.

The socio-political situation in Igboland after the war, therefore, seemed to have in turn encouraged Pentecostalism in the area, giving rise to a situation whereby the strong tie of membership of the mission Churches was loosened. The period was characterized by physical and spiritual poverty, economic depression, deprivation and decline in social activities which created avenues for Pentecostal development. It is believed that the development was first and foremost the work of the Holy Spirit as Luke makes it plain in the book of Acts that the impetus for mission comes from the Holy Spirit (Stott, 1992). Boer (1961) concurs as he notes that:

The Acts is governed by one dominant, overriding and all controlling motif. The motif is the expansion of the faith through the missionary witness in the power of the Spirit... Restlessly the Holy Spirit drives the Church to witness, and continually churches rise out of the witness. (p. 161).

But the development is also a response to local contingencies which the war gave rise to. The war created socio-economic situations that necessitated new religious demands giving birth to 
new and often un-ordained but charismatic itinerant preachers who showcased the hidden qualities of Pentecostalism. Following this development, there sprang up independent Christian groups with evangelical and Pentecostal persuasions, most of which initially claimed to be non-denominational, only to turn round and become Churches later.

Kanayo Nwadialor

Department of Religion and Human Relations

Nnamdi Azikiwe University, Awka, Nigeria

kl.nwadialor@unizik.edu.ng

\section{References}

Achunike, H.C. (2004).The influence of Pentecostalism on Catholic priests and seminarians in Nigeria. Onitsha: Africana First.

Achunike, H.C. (2009). Catholic charismatic movement in Igboland, 1970-1995. Enugu: Fourth Dimension.

Amucheazi, E.G. (1986). Church and politics in eastern Nigeria, 1945-1966. Ibadan: Macmillan.

Anderson, A. (2004). The origins of Pentecostalism and its global spread in the early twentieth century. Lecture for the Oxford Centre for Mission Studies, 5 October 2004, Graduate Institute for Theology and Religion, University of Birmingham

Aniebo, I.N.C. (1983). Of wives, talismans and the dead. London: Heinemann. 
Bolton, F.L. (1992). And we beheld His glory. A personal account of the revival in Eastern Nigeria in 1970/'71, Harlow: Christ the King.

Boer, H.R. (1961). Pentecost and missions. London: Lutterworth.

Burgess, R. (2008). Nigeria's Christian revolution: The civil war Revival and Its Pentecostal Progeny (1976-2006). A Ph.D. Thesis Submitted to Department of Theology, University of Birmingham.

Cerillo, A. (1997). Interpretative approaches to the history of American Pentecostal origins. Pneuma,

19.1, Spring, 29-51

Chuta, S. C. (1986). Africans in the christianization of southern Igboland, 1875-1952. A Ph.D. thesis, Submitted to Department of Religion, University of Nigeria, Nsukka.

Davies, R. E. (1992). I will pour out my spirit: A history and theology of revivals and evangelical awakenings. Tunbridge Wells:

Monarch.

Ewechue, R. (1991). Makers of modern Africa, 2nd Edition. London: African Books.

Goff, J.R, (1988). Charles F. Perham and the missionary origin of Pentecostalism. Fayetteville: University of Arkansas Press.

Hackett, R. I. J. (1983). Power and authority in Nigeria's independent

Churches. West African

Religion, 20.1/2, 37-54.

Hollenweger, J. (1997). Pentecostalism: Origins and development worldwide. Massa chussets: Hendrickson.

Inyama, E.O. (2007). Pentecostalism as urban phenomenon in Nigeria. New Jersey: Goldline.

Iwuagwu, A.O. (1976). The healing ministry in the Church in Nigeria. West African Religion, 17,1, 45-54.

Kalu, O. (2008). African Pentecostalism. London: Oxford Press. 
Kalu, O.U. (1978) Christianity in West Africa: The Nigerian Story. Ibadan: Daystar.

Macchia, F.D. (1996). Tongues and prophecy. Concilium, 3, 63-69.

Miller, A.G. (1996). Pentecostalism as a social movement beyond the theory of deprivation. Journal of Pentecostal Theology, 9.

Ojo, M.A. (1988). The contextual significance of the charismatic movements in independent

Nigeria. Africa, 58, 2, 175-192.

Robert, M. A. (1979). Vision of the disinherited: The making of American Pentecostalism. Peabody: Hendrickson.

Stott, J. (1992). The contemporary Christian. Britain: Intervarsity. Synan, V. (1971). The Holiness-Pentecostal movement in the United States. Grand Rapids. MI: William B. Eerdmans.

Tasie, G. O. M. (1978). Christian missionary enterprise in the Niger Delta. Leidem: E. J. Brill.

Taylor, J. V. (1976). Primal world-views: Christian involvement in Dialogue with traditional thought forms. Ibadan: Daystar.

Zahan, D. (2000). Some reflections on African spirituality. In J. K. Olupona (Ed.). African spirituality: Forms, meanings and expressions. New York: Crossroad. 